\title{
PELATIHAN KOMPUTER DASAR BAGI GURU SEKOLAH LUAR BIASA NEGERI NGABANG
}

\author{
Antonius Setyawan Sugeng Nur Agung, Monika Widyastuti Surtikanti, \\ Masfa Maiza \\ STKIP Pamane Talino, Indonesia \\ a.agung@stkippamanetalino.ac.id
}

\begin{abstract}
The purpose of this community service was helping the special need school- teacher to get through industry 4.0 where computer literacy is very important for improving personal skill, teaching students and fulfilling school administration. The participants of this computer- basic training were 20 teachers form special need-school in Landak regency. The target of this training was the participants were able to mastery three- basic computer program: PowerPoint, Prezi, and Microsoft Excel with the latest version. Those programs were chosen because the teachers need them in their daily life on presenting and teaching (PowerPoint and Prezi) and school administration (Microsoft Excel). The result of the initial observation found that the teacher had low mastery on computer literacy. However, they were eagerly motivated to learn computer. The progress of their computer literacy was obviously seen from their practice during the training. They could design slides of presentation using PowerPoint and Prezi. The most obvious improvement was on their proficiency on using Microsoft Excel. As an example, they used to count the average of the students' report using calculator and mobile phone eventhough they type it on Excel. Nowadays, they can set the automatic formula on their sheet.
\end{abstract}

Keywords: Special Needs School; computer; industry 4.0

\begin{abstract}
Abstrak
Kegiatan pengabdian pada masyarakat ini bertujuan untuk membantu para guru menapaki industri 4.0. Kemampuan penggunaan komputer menjadi sangat penting baik untuk peningkatan kemampuan diri, pengajaran maupun admnistrasi sekolah. Peserta pelatihan komputer dasar ini adalah guru-guru Sekolah Luar Biasa se-kabupaten Landak sebanyak 20 orang. Target dari pelatihan ini adalah mereka mampu menguasai tiga program komputer dasar yaitu: Power Point, Prezi, dan Microsoft Excel dengan versi terbaru. Ketiga program tersebut dipilih untuk diajarkan karena program- program tersebutlah yang paling sering digunakan dalam pengajaran maupun presentasi (PowerPoint \& PrezI) dan administrasi sekolah (Microsoft Exce). Hasil observasi awal yang dilakukan peneliti menemukan bahwa kemampuan penggunaan komputer para guru masih rendah. Meskipun begitu mereka sangat antusias dengan program ini. Motivasi mereka belajar komputer sangat tinggi. Peningkatan kemampuan penggunaan komputer terlihat jelas dari praktek mereka mendesain presentasi di PowerPoint dan Prezi. Peningkatan yang paling signifikan adalah penggunaan Microsoft Exce/ untuk administrasi sekolah. Sebagai contoh, selama ini mereka menghitung rata-rata nilai siswa secara manual dengan kalkulator dan hp walaupun mereka mengetik di Excel. Sekarang mereka sudah bisa mengunakan sheet dan menyeting rumus otomatis didalamnya.
\end{abstract}

Kata Kunci: Sekolah Luar Biasa; komputer; industri 4.0 


\section{Pendahuluan}

Revolusi Industri 4.0 membawa banyak perubahan dan perkembangan teknologi yang salah satunya untuk meningkatkan efisiensi pekerjaan. Modernisasi yang terjadipun merambah hingga dunia pendidikan. Kemajuan teknologi yang ada harus diimbangi juga dengan kemampuan guru dalam menguasai dan menggunakan teknologi. Menurut Colin dalam Shahroom and Hussin (2018) salah satu kunci sukses dalam mempersiapkan diri dalam menapaki revolusi industri 4.0 adalah investasi dalam teknologi. Salah satu teknologi yang paling dekat dengan dengan keseharian guru, selain android adalah penggunaan komputer. Penguasaan komputer diperlukan para guru baik dalam pengajaran maupun administrasi sekolah. Salah satu upaya untuk mendorong guru dalam penguasaan komputer adalah dengan adanya pelatihan. Menurut Irmayani dan Sudirman (2019), pelatihan dilaksanakan dengan beberapa materi yang sesuai dengan kebutuhan mitra.

Survei awal dilakukan pada guru-guru Sekolah Luar Biasa (SLB) di Kabupaten Landak. Dalam penelitian lain yang pernah dilakukan di daerah ini menunjukkan bahwa ketertinggalan infrastruktur pendukung penyelenggaran pendidikan yang berbasis multimedia menemui banyak kendala seperti kestabilan koneksi internet, dan perangkat teknologi (Agung et al, 2020). Namun keterbatasan tersebut tidak menghalangi semangat pembelajaran dan pemanfaatan teknologi informasi dalam menunjang pelaksanaan pembelajaran. Peneliti mempunyai tujuan khusus untuk membuat program pengabdian terhadap guru-guru SLB. Para partisipan ini sengaja dipilih mengingat mereka lebih jarang mendapatkan pelatihan jika dibandingkan dengan guru- guru di sekolah umum khususnya yang sekolah negeri. Menurut penuturan kepala sekolah, kegiatan pengembangan dan pemberdayaan untuk guru-guru di SLB relatif jarang. Sementara itu, guru- guru SLB juga berperan layaknya guru- guru di sekolah lain dimana mereka juga mengajar, membuat serta menyiapkan bahan ajar, dan melakukan pekerjaan administratif persekolahan. Kegiatan- kegiatan tersebut tidak luput dari peran dan penggunaan teknologi khususnya komputer/ laptop. Senada dengan hal tersebut, Scott (2012) mengakui pandangan Marxisme mengakui bahwa teknologi berperan sebagai sarana adaptasi masyarakat (dalam hal ini guru-guru) terhadap lingkungan (dalam hal ini lingkungan sekolah). Undang Undang Guru dan Dosen Nomor 14 Tahun 2005 menyatakan bahwa kompetensi adalah seperangkat pengetahuan, keterampilan, dan perilaku yang harus dimiliki, dihayati, dan dikuasai oleh guru atau dosen dalam melaksanakan tugas profesinya. Selanjutnya masih di dalam undang- undang yang sama, dalam pasal 8 tentang Kompetensi guru disebutkan bahwa kompetensi tersebut meliputi kompetensi pedagogik, kompetensi kepribadian, kompetensi sosial, dan kompetensi professional. Peningkatan kemampuan guru dengan kegiatan pelatihan komputer ini akan benkontribusi dalam meningkatkan kompetensi professional yang menunjang kompetensi pedagogic mereka. Hal ini sesuai dengan penjelasan dalam Standar Kualifikasi Akademik dan Kompetensi Guru bahwa salah satu kompetensi pedagogik inti adalah pemanfaatan teknologi informasi dan komunikasi untuk kepentingan pembelajaran (Permendikbud no 16 tahun 2007).

Gambaran awal yang didapat dari survei ini diketahui bahwa pelatihan penguasaan komputer dasar masih sangat mereka perlukan. Hal ini didasarkan bahwa 
sebagian besar guru masih belum fasih menggunakan komputer dan laptop untuk mengetik, membuat slide presentasi dan membuat sheet.

Rendahnya literasi komputer yang ada berbanding terbalik dengan tuntutan kemajuan teknologi yang semakin maju di era industry 4.0 ini. Sementara menurut Helaluddin (2019), pengaplikasian teknologi merupakan sebagai salah satu bentuk inovasi dengan tujuan untuk mengimbangi dan mengikuti perkembangan zaman. Hal ini membuat program pengabdian ini menjadi sangat penting untuk dilakukan agar mengejar ketertinggalan yang ada sehingga dapat membantu para guru SLB menapaki era industry 4.0. Realisasi dari program ini adalah pelatihan komputer dasar yang meliputi: PowerPoint, Prezi, dan Microsoft Excel. Berdasarkan hasil assesmen awal, ketiga program komputer dasar ini sengaja dipilih untuk dilatihkan karena ketiganya dekat dengan praktek persekolahan sehari-hari. PowerPoint dan Prezi berguna sekali dalam pengajaran ke siswa berkebutuhan khusus. Sedangkan Microsoft Excel penting untuk membantu mereka mengisi laporan admnistrasi sekolah.

Tujuan dari program pelatihan komputer dasar bagi guru-guru SLB ini adalah untuk meningkatkan literasi komputer mereka. Setelah selesai mengikuti program pelatihan komputer dasar ini, para partisipan diharapkan sudah lebih mampu mengoperasikan komputer dengan lebih mandiri. Para partisipan diharapkan bisa mengaplikasikan penggunaan ketiga program komputer yang sudah dilatihkan yaitu: PowerPoint, Prezi, dan Microsoft Excel dalam praktek persekolahan sehari-hari baik dalam pengajaran maupun praktek administrasi sekolah.

\section{Metode}

Kegiatan pengabdian pada masyarakat untuk guru-guru Sekolah Luar Biasa di Kabupaten Landak ini bertempat di SLB Negeri 1 Ngabang. Tim pengabdi pada kegiatan pengabdian kepada masyarakat ini terdiri dari tiga orang dosen dari Program Studi Pendidikan Bahasa Inggris STKIP Pamane Talino. Sedangkan peserta yang mengikuti kegiatan ini adalah guru-guru SLB di kabupaten Landak yang berjumlah sekitar 20 orang. Adapun tiga tahapan kegiatan yang dilakukan meliputi tahapan Persiapan, Pelaksanaan, dan Evaluasi adalah sebagai berikut:

\section{Persiapan Kegiatan}

Beberapa persiapan yang dilakukan dalam tahap persiapan adalah survey kebutuhan mitra dan penentuan topik pelatihan. Survei awal dilakukan terhadap mitra untuk mengetahui permasalahan mitra. Data dari survei awal menjadi dasar untuk melakukan analisis situasi dalam memetakan permasalahan yang muncul. Berdasarkan hasil analisis permasalahan, dicari dan ditentukan tiga program komputer prioritas yang paling tepat untuk dilatihkan yaitu: Power Point, Prezi, dan Microsoft Excel..

\section{Pelaksanaan Kegiatan}

Setelah dipetakan tiga program komputer yang paling penting untuk dijadikan materi pelatihan, yaitu: Power Point, Prezi, dan Microsoft Excel. Selanjutnya, tim 
pengabdi mulai melakukan persiapan kegiatan. Susunan tahapan pelaksanaan kegiatan yang dilakukan adalah sebagai berikut:

a. Koordinasi dengan Kepala Sekolah SLB Negeri 1 Ngabang untuk menentukan tanggal, tempat pelatihan, dan persiapan ruangan.

b. Mencari narasumber yang kompetensinya sesuai dengan materi pelatihan yang akan dilatihkan plus mampu menyiapkan materi pelatihan sesuai dengan program komputer yang sudah ditentukan.

c. Membentuk panitia kecil untuk kelancaran persiapan \& pelaksanaan program pelatihan.

d. Pelaksanaan kegiatan pelatihan komputer pada hari Sabtu, 19 Oktober 2019.

3. Evaluasi Kegiatan

Evaluasi dilaksanakan untuk melihat kembali rangkaian proses persiapan hingga pelaksaanaan dan hasil kegiatan. Data evaluasi ini disajikan secara tabulatif dan naratif. Mengingat tujuan dari kegiatan pengabdian ini adalah untuk membantu para guru SLB menapaki era revolusi industry 4.0 khususnya dalam penggunaan komputer maka rangkuman tangapan dan fakta-fakta di lapangan selama kegiatan tersebut berlangsung menjadi evaluasi hasil yang utama.

\section{Hasil dan Pembahasan}

1. Animo dan motivasi guru- guru dalam mengikuti kegiatan

Jumlah peserta yang mengikuti pelatihan adalah 20 orang guru SLB dari Kabupaten Landak. Kegiatan ini mendapat dukungan dari Program Pendidikan Studi Bahasa Inggris STKIP Pamane Talino sebagai fasilitator. Selain itu SLB Negeri 1 Ngabang sebagai sekolah mitra juga menyambut dengan sangat baik dan sangat senang dengan kegiatan pelatihan ini. Guru- guru yang terlibat dan menjadi partisipan sangat antusias dalam mengikuti kegiatan ini. Mereka menyadari bahwa mahir komputer itu penting dan mereka juga menyadari bahwa selama ini tertinggal oleh tehknologi. Sebagai contoh ketika menghitung nilai siswa meskipun dibuat menggunakan Microsoft Excel namun perhitungan nilai rata-rata masih banyak yang melakukan-nya secara manual dengan kalkulator. Setelah diberi contoh dan diajarkan cara menghitung nilai rata-rata secara otomatis dan memasukkan rumus kedalam sheet, mereka terlihat gembira dan menertawakan metode lama mereka yang masih manual sambil berucap, "Waahh ternyata gampang ya, gak perlu memakai kalkulator lagi". Mereka takjub dengan kemudahan komputasi penghitungan yang mampu mereka operasikan dengan Microsoft Excel.

Hal serupa juga terjadi ketika PowerPoint diajarkan, para partisipan sangat senang ketika bisa membuat animasi dan menambahkan suara ke dalam slide presentasi yang dibuat. Sebelumnya banyak dari partisipan yang hanya membuat plain slides ketika membuat presentasi menggunakan PowerPoint. Sekarang mereka sudah bisa membuat tampilan slides yang menarik baik untuk mengajar ataupun presentasi.

Perbandingan tingkat literasi komputer sebelum dan sesudah pelatihan 
Pelatihan komputer dasar yang diberikan kepada para guru SLB mempunyai peran yang signifikan dalam meningkatkan penguasaan komputer, khususnya untuk ketiga program yang dilatihkan. Perbandingan tingkat literasi komputer para partisipan pada awal sebelum pelatihan adalah sebagai berikut: mahir: 2 orang, sedang: 5 orang, dan kurang: 13 orang. Sedangkan setelah pelatihan ada peningkatan kemampuan penguasaan komputer menjadi: mahir: 4 orang, sedang: 14 orang, dan yang kurang: 1 orang. Pengambaran yang lebih sederhana terkait hasil peningkatan kemampuan penggunaan komputer sebelum dan sesudah pelatihan dilakukan dapat dilihat dalam tabel 1 dan tabel 2 berikut.

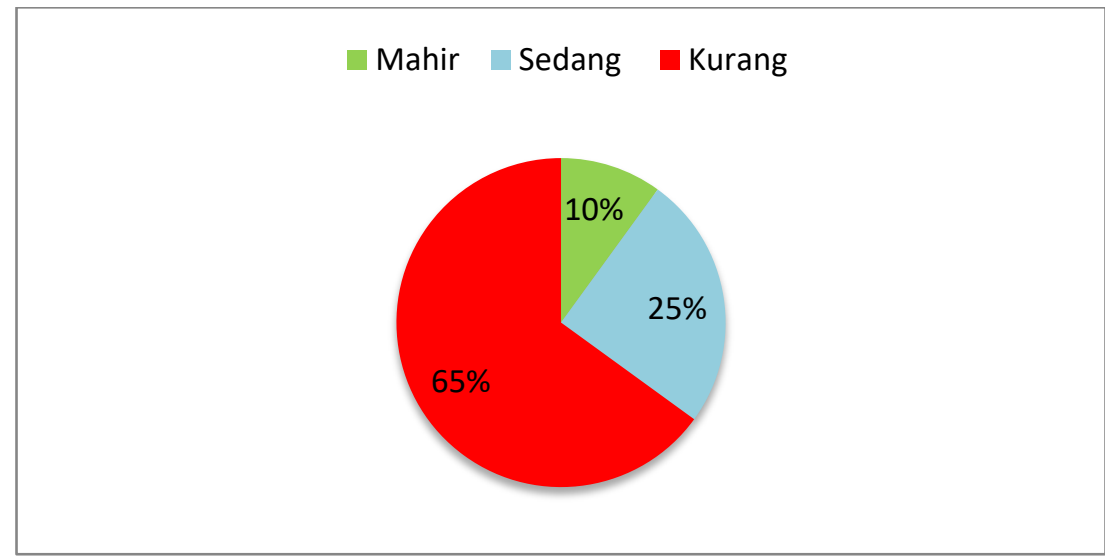

Gambar 1. Tingkat literasi komputer awal

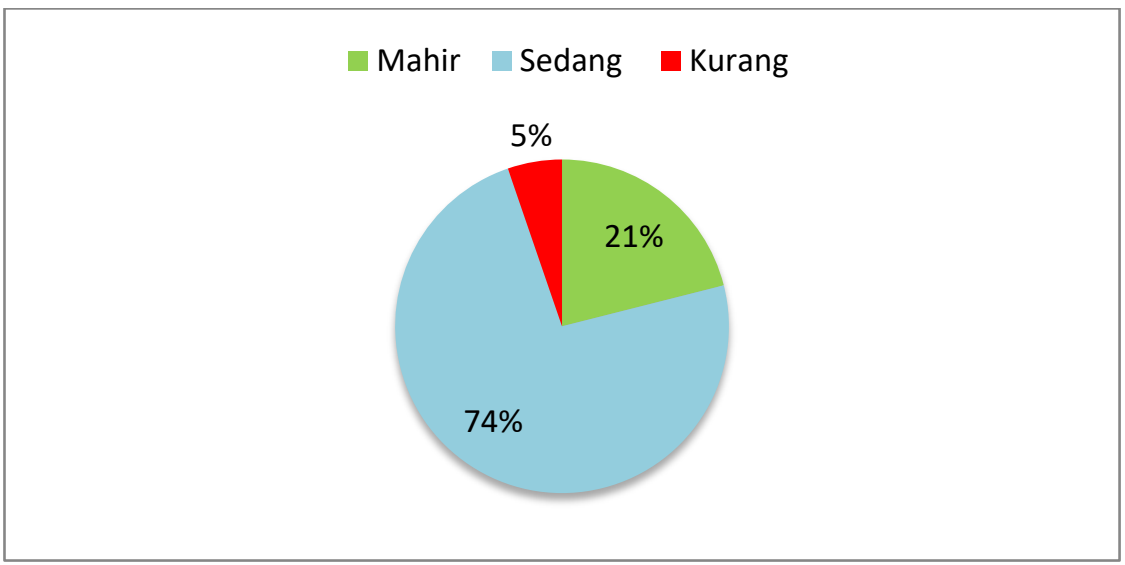

Gambar 2. Tingkat literasi komputer setelah pelatihan

Pelatihan komputer yang sudah dilakukan mempunyai peranan yang sangat penting untuk melatih kefasihan dan menurunkan tingkat kecemasan guru- guru dalam menggunakan komputer. Menurut Larner dan Timberlake (1995), kecemasan sangat berpengaruh terhadap penggunaan komputer khususnya bagi para guru dengan literasi komputer yang rendah sehingga praktek menjadi latihan terbaik bagi mereka. Hal tersebut memang terbukti bahwa pelatihan komputer dasar ini membuat mereka lebih percaya diri. Tingkat kecemasan yang disebabkan oleh ketakutan untuk tidak bisa menggunakan komputer menurun. Praktek pelatihan komputer dasar menjadi sangat penting bagi mereka yang literasi komputernya masih rendah. Menurut Palfrey dan Gasser 
(2008), orang yang tidak mahir digital namun terpaksa harus berkutat dengan dunia digital disebut imigran digital. Berdasarkan hal tersebut, mengingat tingkat literasi komputer yang dimiliki peserta yang ada maka mereka masuk kedalam kategori imigran digital. Penggunaan PowerPoint dan Prezi penting digunakan dalam mengajar siswa berkebutuhan khusus terutama siswa tuna runggu karena cara terbaik bagi mereka untuk belajar adalah secara visual. Hal ini sejalan dengan Hiraga dan Kawashima (2006) dimana visualisasi sangat penting denga tujuan memberi alat bantu yang dapat dilihat. Kedua program komputer diatas dapat memfasilitasi para guru untuk memberi pengajaran visual/ audio/ visual-audio.

\section{Kesimpulan}

Tujuan dari program pelatihan komputer bagi guru- guru SLB di Kabupaten Landak adalah untuk meningkatkan literasi komputer para guru. Pelatihan ini berhasil meningkatkan kemampuan penggunaan komputer dasar khususnya dalam pengaplikasian PowerPoint, Prezi, dan Microsoft Excel untuk menunjang kinerja baik secara praktek akademik maupun administrasi sekolah. Pelatihan seperti ini selain melatih prakteknya juga berperan dalam mengurangi tingkat kecemasan dalam menggunakan komputer karena membuat para guru lebih percaya diri. Mereka tidak merasa cemas lagi ketika harus mengoperasikan komputer.

\section{Daftar Pustaka}

Agung, A. S. N., Surtikanti, M. W., \& Quinones, C. A. (2020). Students' Perception of Online Learning during COVID-19 Pandemic: A Case Study on the English Students of STKIP Pamane Talino. Soshum: Jurnal Sosial dan Humaniora, 10 (2), 225-235.

Helaluddin. (2019). Peningkatan Kemampuan Literasi Teknologi dalam Upaya Mengembangkan Inovasi Pendidikan di Perguruan Tinggi. PENDAIS, 1(1), 44-45.

Hiraga, Rumi. \& Kawashima, Mitsuo. (2006). Performance Visualization for HearingImpaimred Students. Systemics, Cybernetics and Informatics. 3(5), 24-32.

Irmayani \& Sudiran, A.M. (2019). Pengembangan Sumber Daya MManusia Melalui Pelatihan Microsoft Office pada Aparat Desa di Kecamatan Lamasi Timur Kabupaten Luwu Provinsi Sulawesi Selatan. Abdimas Toddopuli: Jurnal Pengabdian Masyarakat. 1(1), 20-27.

Larner, David K. \& Timberlake, Laura M. (1995). Teachers with Limited Computer Knowledge: Variables Affecting Use and Hints to Increase Use. Virginia: Eric.

Palfrey, J. G., \& Gasser, U. (2008). Born digital: Understanding the first generation of digital natives. New York: Basic Books.

Permendiknas No. 16 tahun 2007 tentang Kompetensi Guru.

Scott, John. (2012). Teori Sosial: Masalah- Masalah Pokok dalam Sosiologi. Yogyakarta: Pustaka Pelajar.

Shahroom, Aida A. \& Hussin, Norhayati. (2018). Industrial Revolution 4.0 and Education. International Journal of Academic Research in Business and Social Sciences. 8(9), 314-319.

Undang Undang Republik Indonesia Nomor 14 Tahun 2005 Tentang Guru dan Dosen 